\title{
PHASE FORMATION MECHANISM AND KINETICS IN SOLID-STATE SYNTHESIS OF Ba-DOPED YE'ELIMITE: THE EFFECT OF Ba-DOPING CONCENTRATION ON $\mathrm{C}_{4-x} \mathrm{~B}_{x} \mathrm{~A}_{3} \$$ SYSTEMS
}

\author{
XINGYUAN BAO*, "PIQI ZHAO*, CHEN LIANG**, QUANWEI LI*, SHOUDE WANG*, "XIN CHENG* \\ *Shandong Provincial Key Laboratory of Preparation and Measurement of Building Materials, University of Jinan, \\ Jinan 250022, China \\ **School of Materials Science and Engineering, University of Jinan, \\ Jinan 250022, China
}

"E-mail: mse_zhaopq@ujn.edu.cn, chengxin_ujn@outlook.com

Submitted November 26, 2019; accepted February 24, 2020

\begin{abstract}
Keywords: $\mathrm{C}_{4-x} \mathrm{~B}_{x} \mathrm{~A}_{3} \$$, Ye'elimite, Kinetics, Rietveld, Solid-state reaction
Calcium barium sulfoaluminate (abbr. $\left.C_{4-x} B_{x} A_{3} \$\right)$, one of the special cementitious minerals originated from ye'elimite (abbr. $C_{4} A_{3} \$$ ), has superior hydration and hardening performance. In this paper, a series of $C_{4-x} B_{x} A_{3} \$$ with different Ba-doping concentrations ( $x=0,0.5,1,1.5$ and 2) were prepared, and the effect of the Ba-doping concentration on the formation was systematically investigated by the Rietveld/XRD quantitative phase analysis. The results show that $\mathrm{BaSO}_{4}$ is the essential intermediate phase for the formation of the Ba-doped ye'elimite. The solid-state reaction process of $C_{4-x} B_{x} A_{3} \$$ is separately expressed as two main forms, corresponding to the cases in which the Ba-doping concentration ( $x$ ) is larger than and less than "1", respectively. The Jander diffusion model shows the optimal fitting for $C_{4-x} B_{x} A_{3} \$$ and it clearly proves that the $C_{4-x} B_{x} A_{3} \$$ formation becomes increasingly difficult as the Ba-doping concentration increases. The correlation between the apparent activation energy $\left(E_{a}\right)$ and the Ba-doping concentration is positively well related, which can be expressed as ${ }^{\prime} E_{a}=71.9 x+304^{\prime}\left(\mathrm{kJ} \cdot \mathrm{mol}^{-1}\right)$.
\end{abstract}

\section{ITRODUCTION}

Portland cement is one of the most widely used cementitious materials in land-based architectures, underground projects and marine constructions. However, the drawback of poor durability limits its wide application in severe environments, such as high humidity, high salinealkali and marine environments [1]. In contrast, calcium sulfoaluminate (CSA) cement shows more satisfactory properties and has been well applied to some special projects such as repairing and constructing marine facilities [2, 3]. It has advantages such as higher early strength, faster hardening and better anti-corrosion and anti-permeability properties [4].

The sulfoaluminate $\left(4 \mathrm{CaO} \cdot 3 \mathrm{Al}_{2} \mathrm{O}_{3} \cdot \mathrm{SO}_{3}\right.$, abbreviated as $\mathrm{C}_{4} \mathrm{~A}_{3} \$$ and also named Ye'elimite) as the dominant mineral in CSA, plays a key role in improving the durability in severe environments. It has a sodalite structure with the general composition of $\mathrm{M}_{4}\left[\mathrm{~T}_{6} \mathrm{O}_{12}\right]_{X}$ where $\mathrm{M}=\mathrm{Ca}, \mathrm{T}=\mathrm{Al}$, and $\mathrm{X}=\mathrm{SO}_{4}$ [5-7]. Such a structure possesses four tetragonal and eight hexagonal axial channels with narrow gaps, paralleled in the direction of [001], which is convenient for reactions with water [8-10]. Although CSA performs well in marine engineering, it has not been considered completely satisfactory to meet the increasingly stringent requirements of modern applications. The $\mathrm{C}_{4} \mathrm{~A}_{3} \$$ modification is a feasible strategy, through which new minerals of $\mathrm{C}_{4-x} \mathrm{~B}_{x} \mathrm{~A}_{3} \$$ by barium incorporation have been proven particularly successful in improvement of the performance. $\mathrm{C}_{4-x} \mathrm{~B}_{x} \mathrm{~A}_{3} \$$ has a similar crystal structure, but much higher early strength and better stability $[11,12]$. The study of the formation process is the first and most important step to understand $\mathrm{C}_{4-x} \mathrm{~B}_{x} \mathrm{~A}_{3} \$$. The general solid-state reaction of $\mathrm{C}_{4} \mathrm{~A}_{3} \$$ can start from $950{ }^{\circ} \mathrm{C}$, can form in substantial amounts between $1300-1350{ }^{\circ} \mathrm{C}$ and can decompose when the temperature further rises beyond $1350{ }^{\circ} \mathrm{C}[13,14]$. When $\mathrm{Ba}$ is doped, $\mathrm{C}_{4-x} \mathrm{~B}_{x} \mathrm{~A}_{3} \$$ minerals have a similar formation process and usually form in substantial amounts when the sintering temperature goes higher than $1350{ }^{\circ} \mathrm{C}$ [15-17]. In addition, more $\mathrm{d}$ more researchers have reached an agreement that $\mathrm{Ba}^{2+}$ substitution at the $\mathrm{Ca}^{2+}$-site in $\mathrm{C}_{4} \mathrm{~A}_{3} \$$ had a positive effect on increasing its decomposition temperature [18-20]. Cheng [12] prepared a series of $\mathrm{C}_{4-x} \mathrm{~B}_{x} \mathrm{~A}_{3} \$$ minerals $(0 \leq x \leq 3)$ and demonstrated that $\mathrm{C}_{2.75} \mathrm{~B}_{1.25} \mathrm{~A}_{3} \$$ showed the most satisfactory mechanical property. Lu and Chang [20-24] conducted a more detailed study on the formation process of the $\mathrm{C}_{2.75} \mathrm{~B}_{1.25} \mathrm{~A}_{3} \$$ mineral and obtained the best calcination system of $\mathrm{C}_{2.75} \mathrm{~B}_{1.25} \mathrm{~A}_{3} \$$ minerals.

Although the formation processes of some $\mathrm{C}_{4-x} \mathrm{~B}_{x} \mathrm{~A}_{3} \$$ minerals such as $\mathrm{C}_{3} \mathrm{BA}_{3} \$$ and $\mathrm{C}_{2.75} \mathrm{~B}_{1.25} \mathrm{~A}_{3} \$$ have been 
studied already, the formation and decomposition processes of $\mathrm{C}_{4-x} \mathrm{~B}_{x} \mathrm{~A}_{3} \$$, especially the effect of the Ba-doping concentration on the kinetics of formation, have not been systematically elucidated upon. In this paper, the minerals are prepared according to the molar ratio of $\mathrm{C}_{4-x} \mathrm{~B}_{x} \mathrm{~A}_{3} \$(x=0,0.5,1,1.5$ and 2$)$. The formation rate of the $\mathrm{C}_{4-x} \mathrm{~B}_{x} \mathrm{~A}_{3} \$$ minerals at the different calcination systems are quantified via the Rietveld/XRD method and the comprehensive kinetic of formation is discussed. This study is a step forward to better understanding ye'elimite.

\section{EXPERIMENTAL}

\section{Raw materials}

The analytical pure reagents of $\mathrm{CaCO}_{3}, \mathrm{BaCO}_{3}$, $\mathrm{Al}_{2} \mathrm{O}_{3}$ and $\mathrm{CaSO}_{4} \cdot 2 \mathrm{H}_{2} \mathrm{O}$ (a purity of $99.9 \%$, from the Sinopharm Chemical Reagent Co., Ltd, China) were used in this work to synthesise $\mathrm{C}_{4-x} \mathrm{~B}_{x} \mathrm{~A}_{3} \$$. They were ground and sieved through $74 \mu \mathrm{m}$ prior to being used.

\section{Sample preparation}

Mixtures of the stoichiometric proportion of the above chemical reagents were prepared to synthesise $\mathrm{C}_{4-x} \mathrm{~B}_{x} \mathrm{~A}_{3} \$$, where $x$ was set as $0,0.5,1,1.5$ and 2 , respectively. The resulting powders were firstly ground in a planetary mill with absolute ethanol at $200 \mathrm{rpm}$ for $30 \mathrm{~min}$ and then dried at $50^{\circ} \mathrm{C}$. The powders were finally compressed into thin rectangular samples $(40 \times 40 \times$ $\times 3 \mathrm{~mm}$ ) under $12 \mathrm{MPa}$ pressure. The sintering system of the target minerals $\left(\mathrm{C}_{4} \mathrm{~A}_{3} \$, \mathrm{C}_{3.5} \mathrm{~B}_{0.5} \mathrm{~A}_{3} \$, \mathrm{C}_{3} \mathrm{BA}_{3} \$\right.$, $\mathrm{C}_{2.5} \mathrm{~B}_{1.5} \mathrm{~A}_{3} \$$, and $\mathrm{C}_{2} \mathrm{~B}_{2} \mathrm{~A}_{3} \$$ ) were slightly varied and detailed in Table 1, where the sintering duration (SD) meant the time-period under a certain sintering temperature. A total of 225 samples were scanned under an X-ray diffractometer and finally evaluated by the Rietveld/ XRD quantitative analysis.

Table 1. The sintering system design for the target $\mathrm{C}_{4-x} \mathrm{~B}_{x} \mathrm{~A}_{3} \$$ minerals*.

\begin{tabular}{ccc}
\hline $\begin{array}{c}\text { Ba-doping } \\
\text { concentration } \\
(\mathrm{mol})\end{array}$ & $\begin{array}{c}\text { Sintering } \\
\text { temperature } \\
\left({ }^{\circ} \mathrm{C}\right)\end{array}$ & $\begin{array}{c}\text { Sintering } \\
\text { duration } \\
(\mathrm{min})\end{array}$ \\
\hline 0 & 1200 & 0 \\
0.5 & 1250 & 30 \\
1 & 1300 & 60 \\
1.5 & 1350 & 90 \\
2 & 1400 & 120 \\
- & - & 240 \\
- & - & 480 \\
- & - & 720 \\
- & - & 1200 \\
\hline
\end{tabular}

* In this experiment design, the 225 samples were obtained through rearranging and combining based on factors of the Ba-doping (5 levels), the sintered temperature (5 levels) and the sintered time (9 levels).

\section{Testing methods}

The XRD patterns were recorded in the BraggBrentano reflection geometry $(\theta / 2 \theta)$ on a D8 ADVANCE (Bruker AXS) diffractometer. The detailed instrument settings for the XRD are summarised in Table 2. The Rietveld refinement was implemented by using TOPAS 4.2 software. The refined overall parameters were the cell parameters, zero-shift error, background, phase scale and peak shape parameters using the fundamental parameters approach [25-27].

Table 2. The XRD instrument settings.

\begin{tabular}{lc}
\hline Parameter & Step scanning \\
\hline X-ray radiation power & $40 \mathrm{kV} / 40 \mathrm{~mA}$ \\
Wavelength type: CuK $\alpha 1$ & $\mathrm{~K} \alpha 1=1.5406 \AA$ \\
Detector & $\mathrm{X}^{\prime}$ Celerator detector \\
Divergence slit $\left({ }^{\circ}\right)$ & 1.00 \\
Soller slit $(\mathrm{rad})$ & 0.04 \\
Receiving slit $\left({ }^{\circ}\right)$ & 0.6 \\
Step width $\left({ }^{\circ}\right)$ & 0.02 \\
Measure time $(\mathrm{h})$ & 0.5 \\
Scan range $\left(2 \theta /{ }^{\circ}\right)$ & $5-70$ \\
\hline
\end{tabular}

\section{RESULTS AND DISCUSSIONS}

\section{Formation Process of $\mathrm{C}_{4-\mathrm{x}} \mathrm{B}_{\mathrm{x}} \mathrm{A}_{3} \$$ Minerals}

A series of $\mathrm{C}_{4-x} \mathrm{~B}_{x} \mathrm{~A}_{3} \$$ minerals with different Ba-doping concentrations were prepared by solid-state reaction. The XRD qualitative analysis of the samples with the different sintering systems was firstly performed and the selected XRD patterns for the samples sintered at $1300{ }^{\circ} \mathrm{C}$ for 4 hours are shown in Figure 1. For $\mathrm{C}_{4} \mathrm{~A}_{3} \$$, most diffraction peaks show stoichiometric ye'elimite itself. The formation is mainly governed by Equations (1-4):

$$
\begin{gathered}
\mathrm{CaO}+\mathrm{Al}_{2} \mathrm{O}_{3} \rightarrow \mathrm{CaAl}_{2} \mathrm{O}_{4} \\
12 \mathrm{CaO}+7 \mathrm{Al}_{2} \mathrm{O}_{3} \rightarrow \mathrm{Ca}_{12} \mathrm{Al}_{14} \mathrm{O}_{33} \\
\mathrm{CaSO}_{4}+3 \mathrm{CaAl}_{2} \mathrm{O}_{4} \rightarrow \mathrm{Ca}_{4} \mathrm{Al}_{6} \mathrm{SO}_{16} \\
\mathrm{CaSO}_{4}+1 / 4 \mathrm{Ca}_{12} \mathrm{Al}_{14} \mathrm{O}_{33}+5 / 4 \mathrm{Al}_{2} \mathrm{O}_{3} \rightarrow \\
\rightarrow \mathrm{Ca}_{4} \mathrm{Al}_{6} \mathrm{SO}_{16}+3 \mathrm{CO}_{2} \uparrow
\end{gathered}
$$

Some impurity peaks with very low intensity are detected as $\mathrm{Ca}_{12} \mathrm{Al}_{14} \mathrm{O}_{33}\left(\mathrm{C}_{12} \mathrm{~A}_{7}\right), \mathrm{Ca}_{3} \mathrm{Al}_{2} \mathrm{O}_{6}\left(\mathrm{C}_{3} \mathrm{~A}\right)$ and $\mathrm{CaAl}_{2} \mathrm{O}_{4}(\mathrm{CA})$, respectively. For $\mathrm{CA}$ and $\mathrm{C}_{12} \mathrm{~A}_{7}$, the reason is mainly due to the decomposition of a small amount of gypsum, leading to sulfate insufficiency, which has been well accepted already in some previous studies [28-37]. The presence of $\mathrm{C}_{3} \mathrm{~A}$ here could be attributed as the $\mathrm{C}_{4} \mathrm{~A}_{3} \$$ decomposition according to Equation (5) [29]:

$\mathrm{Ca}_{4} \mathrm{Al}_{6} \mathrm{O}_{12} \mathrm{SO}_{4}+5 \mathrm{CaO} \rightarrow 3 \mathrm{Ca}_{3} \mathrm{Al}_{2} \mathrm{O}_{6}+\mathrm{SO}_{2}+1 / 2 \mathrm{O}_{2} \uparrow$ 


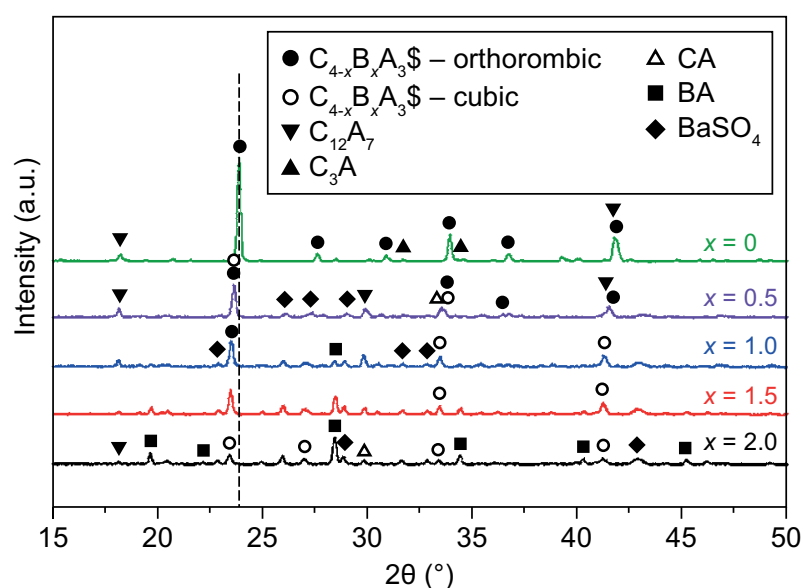

Figure 1. The XRD patterns of the $\mathrm{C}_{4-\mathrm{x}} \mathrm{B}_{x} \mathrm{~A}_{3} \$$ systems sintered at $1300{ }^{\circ} \mathrm{C}$ for $4 \mathrm{~h}$.

When $\mathrm{Ba}^{2+}$ is doped, the impurity phase assemblage tends to be complicated, including $\mathrm{BaSO}_{4}(\mathrm{~B} \$), \mathrm{BaAl}_{2} \mathrm{O}_{4}$ (BA), $\mathrm{CA}$ and $\mathrm{C}_{12} \mathrm{~A}_{7}$. $\mathrm{B} \$$ and $\mathrm{BA}$ are formed as the intermediate phases according to Equations (6) and (7), respectively. Based on the analysis of the stoichiometric ye'elimite [31, 32], the formation process of $\mathrm{C}_{4-\mathrm{x}} \mathrm{B}_{\mathrm{x}} \mathrm{A}_{3} \$$ can be proposed as Equations (8-10), where Equation (8) and Equations (9-10) describe the cases of ' $x<1$ ' and ' $x>1$ ', respectively. $\mathrm{BaSO}_{4}$ is preferentially formed no matter how much $\mathrm{Ba}^{2+}$ is doped, which is due to its better stability at a high temperature [31]. Also, the peak intensity of $\mathrm{C}_{4-x} \mathrm{~B}_{x} \mathrm{~A}_{3} \$$ gradually decreases with an increase in the Ba-doping concentration. They both indicate that the solid-state reaction becomes more difficult after the barium incorporation. In addition, the XRD patterns clearly show that the main peak of $\mathrm{C}_{4-x} \mathrm{~B}_{x} \mathrm{~A}_{3} \$$ $\left(2 \theta=23.44-23.88^{\circ}\right)$ has a gradual left-shift in the position, which reflects that the cell volume became significantly enlarged based on the barium incorporation. The detailed results are reported in the following Rietveld analysis.

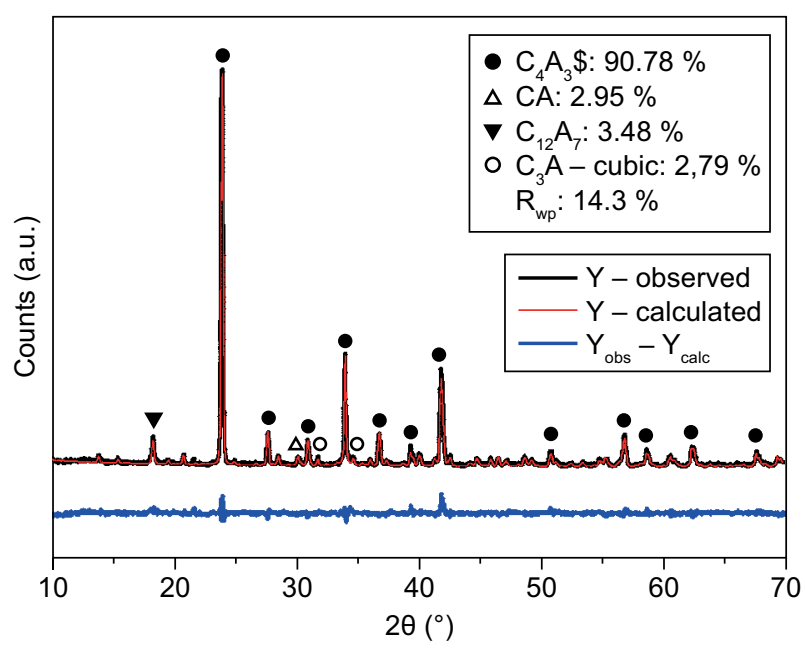

Figure 2. The result of the Rietveld quantitative phase analysis of the $\mathrm{C}_{4} \mathrm{~A}_{3} \$$ mineral.

$$
\begin{gathered}
\mathrm{BaO}+\mathrm{CaSO}_{4} \rightarrow \mathrm{BaSO}_{4}+\mathrm{CaO} \\
\mathrm{BaO}+\mathrm{Al}_{2} \mathrm{O}_{3} \rightarrow \mathrm{BaAl}_{2} \mathrm{O}_{4} \\
x \mathrm{BaSO}_{4}+(1-x) \mathrm{CaSO}_{4}+3 \mathrm{CaAl}_{2} \mathrm{O}_{4} \rightarrow \\
\rightarrow \mathrm{Ca}_{(4-x)} \mathrm{Ba}_{x} \mathrm{Al}_{6} \mathrm{SO}_{16} \\
\mathrm{BaSO}_{4}+(x-1) \mathrm{BaO}+(4-x) \mathrm{CaO}+ \\
+3 \mathrm{Al}_{2} \mathrm{O}_{3} \rightarrow \mathrm{Ca}_{(4-x)} \mathrm{Ba}_{x} \mathrm{Al}_{6} \mathrm{SO}_{16} \\
\mathrm{BaSO}_{4}+(x-1) \mathrm{BaAl}_{2} \mathrm{O}_{4}+(4-x) \mathrm{CaAl}_{2} \mathrm{O}_{4} \rightarrow \\
\rightarrow \mathrm{Ca}_{(4-x)} \mathrm{Ba}_{x} \mathrm{Al}_{6} \mathrm{SO}_{16}
\end{gathered}
$$

The Rietveld quantitative results of the above selected XRD patterns (the $\mathrm{C}_{4-x} \mathrm{~B}_{x} \mathrm{~A}_{3} \$$ minerals sintered at $1300{ }^{\circ} \mathrm{C}$ for 4 hours) are shown in Table 3 . Wherein, one representative Rietveld refinement plot of the $\mathrm{C}_{4} \mathrm{~A}_{3} \$$ sample is shown in Figure 2. Based on the low $R_{w p}$ values $(<15 \%$, the value is the difference between the calculated result via the TOPAS 4.2 software and the observed data) and the smooth difference curve of the Rietveld refinement indicated that the fittings are satisfactory. The quantitative results of $\mathrm{C}_{4-x} \mathrm{~B}_{x} \mathrm{~A}_{3} \$$ (both orthorhombic and cubic structures) basically follow a decreasing trend

Table 3. The Rietveld quantitative phase analysis of the $\mathrm{C}_{4-\mathrm{x}} \mathrm{B}_{x} \mathrm{~A}_{3} \$$ samples sintered at $1300{ }^{\circ} \mathrm{C}$ for $4 \mathrm{~h}$.

\begin{tabular}{clcccccc}
\hline Analysis & Phases and R-factors & $\mathrm{C}_{4} \mathrm{~A}_{3} \$$ & $\mathrm{C}_{3.5} \mathrm{~B}_{0.5} \mathrm{~A} 3 \$$ & $\mathrm{C}_{3} \mathrm{BA}_{3} \$$ & $\mathrm{C}_{2.5} \mathrm{~B}_{1.5} \mathrm{~A}_{3} \$$ & $\mathrm{C}_{2} \mathrm{~B}_{2} \mathrm{~A}_{3} \$$ & ICSD codes \\
\hline & Ye'elimite_orthorhombic & $90.8(4)$ & $20.8(3)$ & $10.6(3)$ & $10.4(2)$ & $8.9(1)$ & 80361 \\
& Ye'elimite_cubic & - & $6.1(3)$ & $21.7(4)$ & $18.1(2)$ & $18.9(2)$ & 81654 \\
Quantita- & $\mathrm{C}_{3} \mathrm{~A}$ & $2.8(2)$ & $1.2(1)$ & - & - & - & 1841 \\
tive results & $\mathrm{C}_{12} \mathrm{~A}_{7}$ & $3.5(2)$ & $27.4(4)$ & $16.5(2)$ & $7.1(1)$ & $6.8(1)$ & 29212 \\
$($ wt.\%) & $\mathrm{CA}$ & $2.9(2)$ & $36.1(5)$ & $29.7(4)$ & $27.4(3)$ & $27.1(4)$ & 260 \\
& $\mathrm{BaSO}_{4}$ & - & $6.9(2)$ & $16.7(2)$ & $24.9(2)$ & $25.7(2)$ & 16904 \\
& $\mathrm{BaAl}_{2} \mathrm{O}_{4}$ & - & $1.5(1)$ & $4.7(1)$ & $12.1(1)$ & $12.6(2)$ & 10036 \\
\hline Cell volu- & Ye'elimite_orthorhombic & $1.55 \times 10^{-21}$ & $1.56 \times 10^{-21}$ & $1.57 \times 10^{-21}$ & $1.61 \times 10^{-21}$ & $1.61 \times 10^{-21}$ & - \\
me $\left(\mathrm{cm}^{3}\right)$ & Ye'elimite_cubic & - & $7.90 \times 10^{-22}$ & $7.91 \times 10^{-22}$ & $8.00 \times 10^{-22}$ & $8.03 \times 10^{-22}$ & - \\
\hline Criteria of fit & $\mathrm{R}_{\mathrm{wP}}(\%)$ & 14.3 & 14.8 & 12.8 & 13.9 & 14.1 & - \\
\hline
\end{tabular}


as the Ba-doping concentration increases with the exception of $\mathrm{C}_{3.5} \mathrm{~B}_{0.5} \mathrm{~A}_{3} \$$. That exception is probably due to the current sintering temperature that could not fully satisfy the requirement of the $\mathrm{C}_{3.5} \mathrm{~B}_{0.5} \mathrm{~A}_{3} \$$ formation. Meanwhile, the Ba-doping concentration is not high enough for the sulfur solidification. With the prolonged sintering time, excessive sulfur volatilisthe ing from $\mathrm{CaSO}_{4}$ decomposition restricts the formation of ye'elimite. The cell volume of ye'elimite in both the orthorhombic and cubic structures are also reported in Table 3, directly proving the growing tendency based on the barium incorporation. For the impurity phase of $\mathrm{C}_{3} \mathrm{~A}$, it decreases gradually and disappears when the Ba-doping concentration is larger than $1.0(x>1)$. The Ba-doped ye'elimite has a relatively higher decomposition temperature, which is consistent with the above analysis, indicating that $\mathrm{C}_{3} \mathrm{~A}$ is mainly from the decomposition process of ye'elimite. As expected, the quantitative results of $\mathrm{BaSO}_{4}$ and $\mathrm{BaAl}_{2} \mathrm{O}_{4}$ show a gradually growing tendency with an increase in the Ba-doping concentration and reaches a stable level with the further addition. The basic trend is consistent with that of 'Ye'elimite_orthorhombic'. However, for 'Ye'elimite_cubic', it shows a slightly lower amount in the sample of $\mathrm{C}_{2.5} \mathrm{~B}_{1.5} \mathrm{~A}_{3} \$$ and $\mathrm{C}_{2} \mathrm{~B}_{2} \mathrm{~A}_{3} \$$ compared with that in $\mathrm{C}_{3} \mathrm{BA}_{3} \$$. It again indicates that an increase in the Ba-doping concentration brings more difficulty for the formation of $\mathrm{C}_{4-x} \mathrm{~B}_{x} \mathrm{~A}_{3} \$$.

\section{Conversion rate of $\mathrm{C}_{4-x} \mathrm{~B}_{x} \mathrm{~A}_{3} \$$}

The conversion rates of the Ba-doped ye'elimite under the individual conditions, versus the temperature, sintering duration and Ba-doping concentration, were determined based on the above Rietveld/XRD quantitative analysis. The results are detailed in Figure 3. For $\mathrm{C}_{4} \mathrm{~A}_{3} \$$ (Figure $3 \mathrm{a}$ ), the representative formation process is consis-tent with previous studies, which provides basic rules for studying the Ba-doped ye'elimite [13, 28, 3339]. The mass fraction of $C_{4} A_{3} \$$ gradually increases with the prolonged sintering time. When the temperature is between $1200{ }^{\circ} \mathrm{C}$ and $1300{ }^{\circ} \mathrm{C}$, the reaction rate (slope of a certain point) shows a gradually decreasing tendency with a longer sintering duration. This is mainly caused by the slower diffusion in the late stage of the solid-state reaction. In comparison, the effect of the temperature on the conversion rate is more significant than the sintering duration. The conversion rate can reach a completely high level (>90 wt. \%) within a short time (30 - $60 \mathrm{~min})$ above $1350{ }^{\circ} \mathrm{C}$. It indicates that fast sintering at a high temperature is helpful in obtaining $\mathrm{C}_{4} \mathrm{~A}_{3} \$$ with a high purity. It is noteworthy that the raw materials were calcinated in a relatively closed furnace and that the fast sintering can obviously reduce the harmful effect of the sulfur escape.

The conversation rates of $\mathrm{C}_{3.5} \mathrm{~B}_{0.5} \mathrm{~A}_{3} \$, \mathrm{C}_{3} \mathrm{BA}_{3} \$$, $\mathrm{C}_{2.5} \mathrm{~B}_{1.5} \mathrm{~A}_{3} \$$ and $\mathrm{C}_{2} \mathrm{~B}_{2} \mathrm{~A}_{3} \$$ under the conditions of the different temperature and sintering duration are plotted in Figure 3b-e, respectively. As $\mathrm{C}_{4-x} \mathrm{~B}_{x} \mathrm{~A}_{3} \$(x>0)$ originates from $\mathrm{C}_{4} \mathrm{~A}_{3} \$$, they have a similar formation process. However, compared with $\mathrm{C}_{4} \mathrm{~A}_{3} \$$, the conversion rate of the Ba-doped ye'elimite is significantly reduced

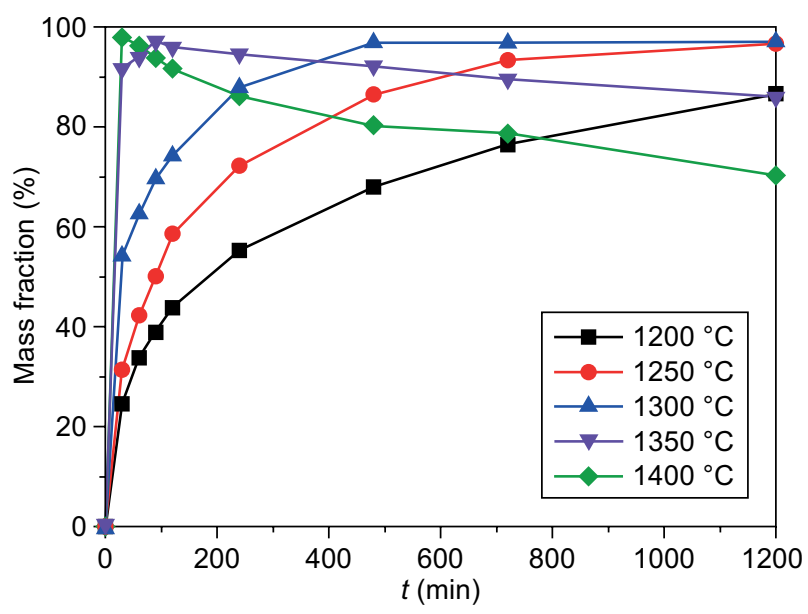

a) $\mathrm{C}_{4} \mathrm{~A}_{3} \$$

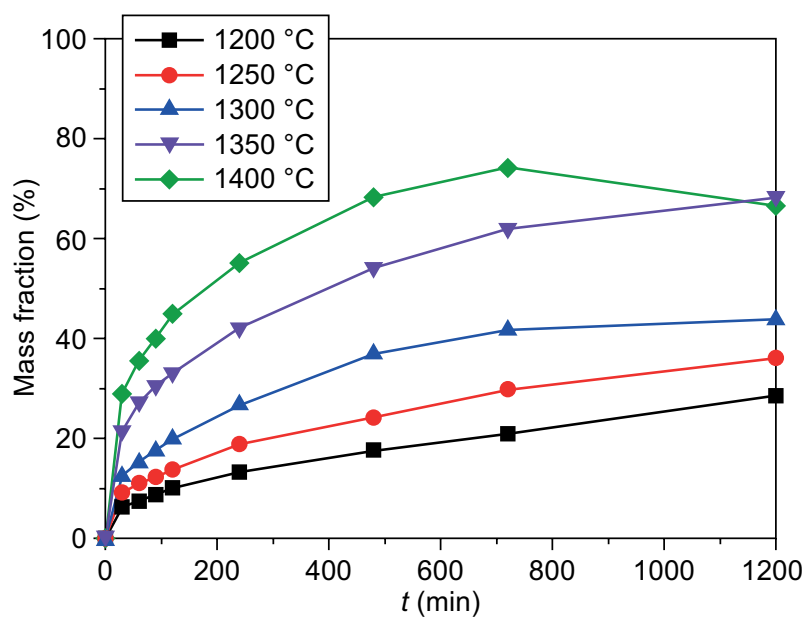

b) $\mathrm{C}_{3.5} \mathrm{~B}_{0.5} \mathrm{~A}_{3} \$$

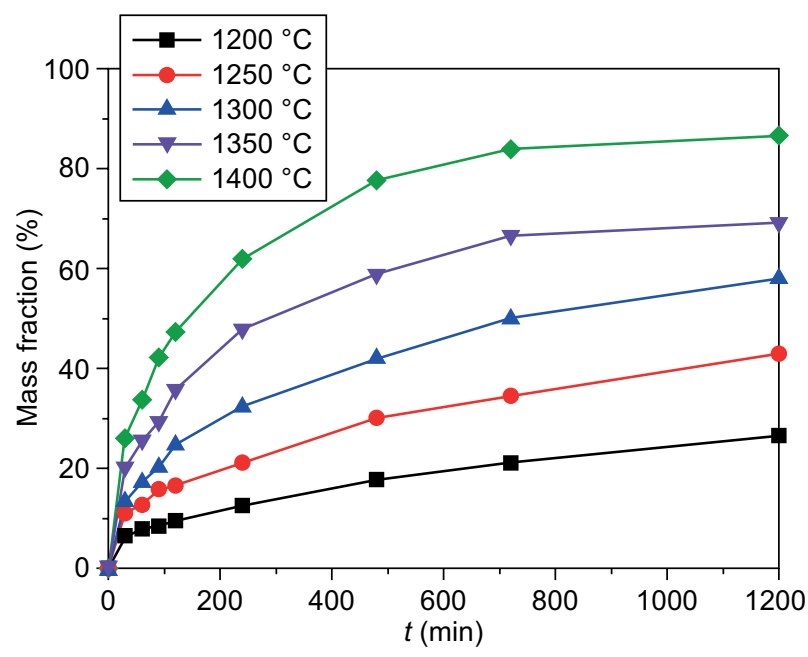

c) $\mathrm{C}_{3} \mathrm{BA}_{3} \$$

Figure 3. The conversion rate of the $\mathrm{C}_{4-x} \mathrm{~B}_{x} \mathrm{~A}_{3} \$$ minerals. (Continue on next page) 


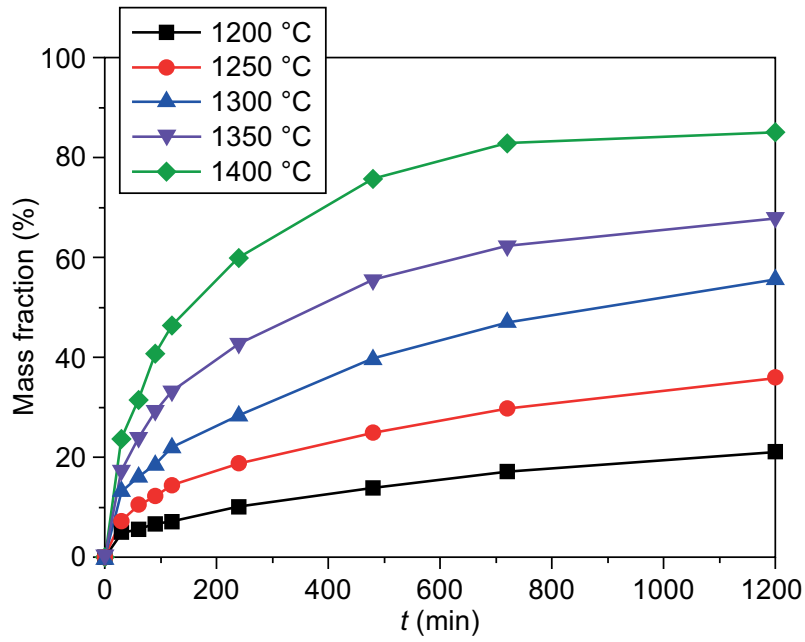

d) $\mathrm{C}_{2.5} \mathrm{~B}_{1.5} \mathrm{~A}_{3} \$$

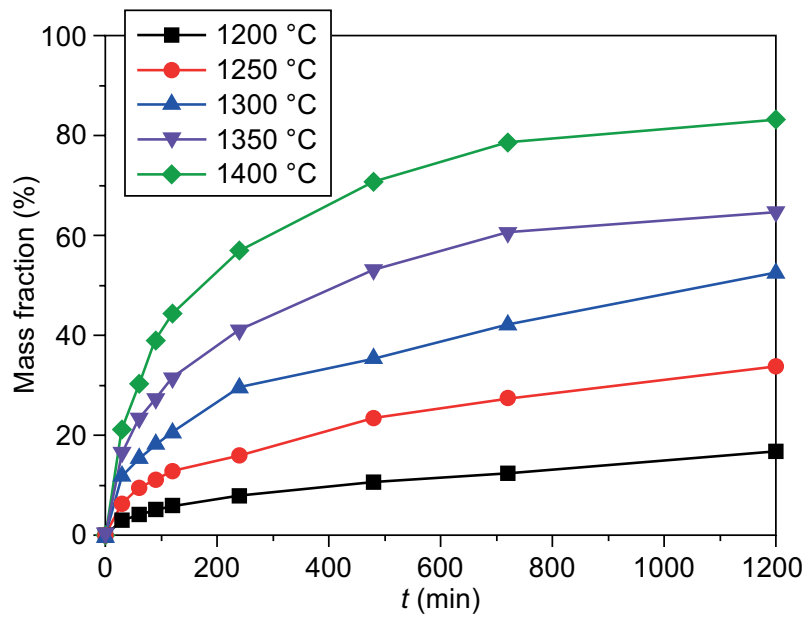

e) $\mathrm{C}_{2} \mathrm{~B}_{2} \mathrm{~A}_{3} \$$

Figure 3. The conversion rate of the $\mathrm{C}_{4-x} \mathrm{~B}_{x} \mathrm{~A}_{3} \$$ minerals (figs. 3a-e represent the conversion rate of $\mathrm{C}_{4} \mathrm{~A}_{3} \$, \mathrm{C}_{3.5} \mathrm{~B}_{0.5} \mathrm{~A}_{3} \$, \mathrm{C}_{3} \mathrm{~B} \mathrm{~A}_{3} \$$, $\mathrm{C}_{2.5} \mathrm{~B}_{1.5} \mathrm{~A}_{3} \$, \mathrm{C}_{2} \mathrm{~B}_{2} \mathrm{~A}_{3} \$$, respectively).

under the same calcination conditions. It is easy to come to the conclusion that the $\mathrm{C}_{4-x} \mathrm{~B}_{x} \mathrm{~A}_{3} \$$ formation becomes increasingly difficult with an increase in the Ba-doping concentration. Since the radius of $\mathrm{Ba}^{2+}(135 \mathrm{pm})$ is much larger than that of $\mathrm{Ca}^{2+}(100 \mathrm{pm})$, it is easy to understand that it requires much more energy to form Ba-doped ye'elimite. A similar conclusion is also reported with the aluminate minerals. The formation activation energy of the Ba-doped aluminate (about $286.92 \mathrm{~kJ} \cdot \mathrm{mol}^{-1}$ ) is higher than the stoichiometric one (about $197.76 \mathrm{~kJ} \cdot \mathrm{mol}^{-1}$ ) [43]. Another difference is that there is no significant decomposition phenomenon among the $\mathrm{C}_{4-\mathrm{x}} \mathrm{B}_{\mathrm{x}} \mathrm{A}_{3} \$$ minerals, except $\mathrm{C}_{3.5} \mathrm{~B}_{0.5} \mathrm{~A}_{3} \$$ at $1400{ }^{\circ} \mathrm{C}$. It can be illustrated that the $\mathrm{Ba}^{2+}$ substitution at the $\mathrm{Ca}^{2+}$-site in $\mathrm{C}_{4} \mathrm{~A}_{3} \$$ can significantly enhance its thermal stability, which is also reported elsewhere [20]. The reason can be explained by the difference in the bond dissociation energies between $\mathrm{Ba}-\mathrm{O}\left(562 \pm 13.4 \mathrm{~kJ} \cdot \mathrm{mol}^{-1}\right)$ and $\mathrm{Ca}-\mathrm{O}(383.3$ $\left.\pm 5.0 \mathrm{~kJ} \cdot \mathrm{mol}^{-1}\right)[41]$.

\section{The formation kinetics model of the $\mathrm{C}_{4-x} \mathrm{~B}_{x} \mathrm{~A}_{3} \$$ minerals}

In this part, appropriate kinetics models are discussed and selected to study the effect of the Ba-doping concentration on the $\mathrm{C}_{4-x} \mathrm{~B}_{x} \mathrm{~A}_{3} \$$ formation process. The key to selecting the kinetics models is primarily based on the statistical fitting of the mathematical models by the evaluation of the correlation coefficient $\left(\mathrm{R}^{2}\right)$ values and the standard deviation [42]. Notably, the decomposition points (such as the points of $\mathrm{C}_{4} \mathrm{~A}_{3} \$$ at $1300{ }^{\circ} \mathrm{C}, 1350{ }^{\circ} \mathrm{C}$ and $1400{ }^{\circ} \mathrm{C}$ in Figure $3 \mathrm{a}$ ) are not taken into consideration in this study. All of the to-be-assessed models $[42,43]$ are listed in Table 4 . They can be summarised by the function $f(\alpha)=\mathrm{K}_{(\mathrm{T}, \mathrm{C})} t+C$, where $\mathrm{K}$ is the rate constant and ' $\alpha$ ' represents the mass fraction of $\mathrm{C}_{4-x} \mathrm{~B}_{x} \mathrm{~A}_{3} \$$ at a certain sintering duration (abbr. ' $t$ ' in the above equation). The results show that the highest $\mathrm{R}^{2}$ values (Table 5) are yielded from the Jander model, where the standard deviation is also the minimum. Therefore, the Jander model is selected to perform the kinetic calculation in the following work. The relationship

Table 4. The solid-state reaction and kinetic models.

\begin{tabular}{llll}
\hline $\begin{array}{l}\text { Equation } \\
\text { number }\end{array}$ & Kinetics equation & Reaction mechanism & Kinetics model \\
\hline $\mathrm{D}_{1}$ & $\mathrm{D}_{1}=\alpha^{2}=\mathrm{K}_{\mathrm{T}} \mathrm{t}$ & One-dimensional diffusion mechanism & Flat model \\
\hline $\mathrm{D}_{2}$ & $\mathrm{D}_{2}=(1-\alpha) \ln (-\alpha)+\alpha=\mathrm{K}_{\mathrm{T}} \mathrm{t}$ & Two-dimensional diffusion mechanism & Cylindrical model \\
\hline $\mathrm{D}_{3}$ & $\mathrm{D}_{3}=\left[1-(1-\alpha)^{1 / 3}\right]^{2}=\mathrm{K}_{\mathrm{T}} \mathrm{t}$ & Three-dimensional diffusion mechanism & Jander equation \\
\hline $\mathrm{D}_{4}$ & $\mathrm{D}_{4}=1-2 \alpha / 3-(1-\alpha)^{2 / 3}=\mathrm{K}_{\mathrm{T}} \mathrm{t}$ & Three-dimensional diffusion mechanism & Glinstling equation \\
\hline $\mathrm{R}_{1}$ & $\mathrm{R}_{1}=-\ln (1-\alpha)=\mathrm{K}_{\mathrm{C}} \mathrm{t}$ & Interfacial chemical & $\begin{array}{l}\text { Spherical model } \\
\text { (first order reaction) }\end{array}$ \\
\hline $\mathrm{R}_{2}$ & $\mathrm{R}_{2}=1-(1-\alpha)^{1 / 2}=\mathrm{K}_{\mathrm{C}} \mathrm{t}$ & Interfacial chemical & $\begin{array}{l}\text { Cylindrical model } \\
\text { (second order reaction) }\end{array}$ \\
\hline $\mathrm{R}_{3}$ & $\mathrm{R}_{3}=1-(1-\alpha)^{1 / 3}=\mathrm{K}_{\mathrm{C}} \mathrm{t}$ & Reaction mechanism & $\begin{array}{l}\text { Spherical model } \\
\text { (third order reaction) }\end{array}$ \\
\hline
\end{tabular}


curves of ' $f(\alpha)-\mathrm{K}_{(\mathrm{T} . \mathrm{C})} t$ ' of the $\mathrm{C}_{4-x} \mathrm{~B}_{x} \mathrm{~A}_{3} \$$ minerals are shown in Figure $4 \mathrm{a}-\mathrm{e}$, respectively.

After the linear fitting of time and $f(\alpha)$, the reaction rate constants, i.e., the $\mathrm{k}$ value, which quantitatively represents the chemical reaction velocity and changes with temperature can be obtained by the calculated slopes. The reaction rate constants with the different
Ba-doping concentration and temperature are depicted in Figure 5. The chart illustrates that the constant $k$ gradually increases with the rise in the temperature for the same mineral. Another phenomenon is that it shows a general decline with an increase in the Ba-doping concentration. However, one singular point, where the Ba-doping concentration appears to be 0.5 , shows

Table 5. The result of the linear regression analysis.

\begin{tabular}{cccccc}
\hline \multirow{2}{*}{$\begin{array}{c}\text { Equation } \\
\text { number }\end{array}$} & \multicolumn{5}{c}{ The average value of $\mathrm{R}^{2}$} \\
\cline { 2 - 6 } & $\mathrm{C}_{4} \mathrm{~A}_{3} \$$ & $\mathrm{C}_{3.5} \mathrm{~B}_{0.5} \mathrm{~A}_{3} \$$ & $\mathrm{C}_{3} \mathrm{BA}_{3} \$$ & $\mathrm{C}_{2.5} \mathrm{~B}_{1.5} \mathrm{~A}_{3} \$$ & $\mathrm{C}_{2} \mathrm{~B}_{2} \mathrm{~A}_{3} \$$ \\
\hline $\mathrm{D}_{1}$ & 0.7162 & 0.9694 & 0.9582 & 0.9713 & 0.9779 \\
$\mathrm{D}_{2}$ & 0.8410 & 0.9831 & 0.9768 & 0.9858 & 0.9898 \\
$\mathrm{D}_{3}$ & 0.9942 & 0.9932 & 0.9896 & 0.9953 & 0.9960 \\
$\mathrm{D}_{4}$ & 0.9466 & 0.9872 & 0.9823 & 0.9901 & 0.9929 \\
$\mathrm{R}_{1}$ & 0.8458 & 0.8941 & 0.8946 & 0.9226 & 0.9332 \\
$\mathrm{R}_{2}$ & 0.8788 & 0.8513 & 0.8476 & 0.8820 & 0.8959 \\
$\mathrm{R}_{3}$ & 0.9315 & 0.8664 & 0.8646 & 0.8971 & 0.9095 \\
\hline Standard & 0.005508 & 0.005059 & 0.0075 & 0.002854 & 0.002513 \\
deviation of $\mathrm{D}_{3}$ & & & & &
\end{tabular}

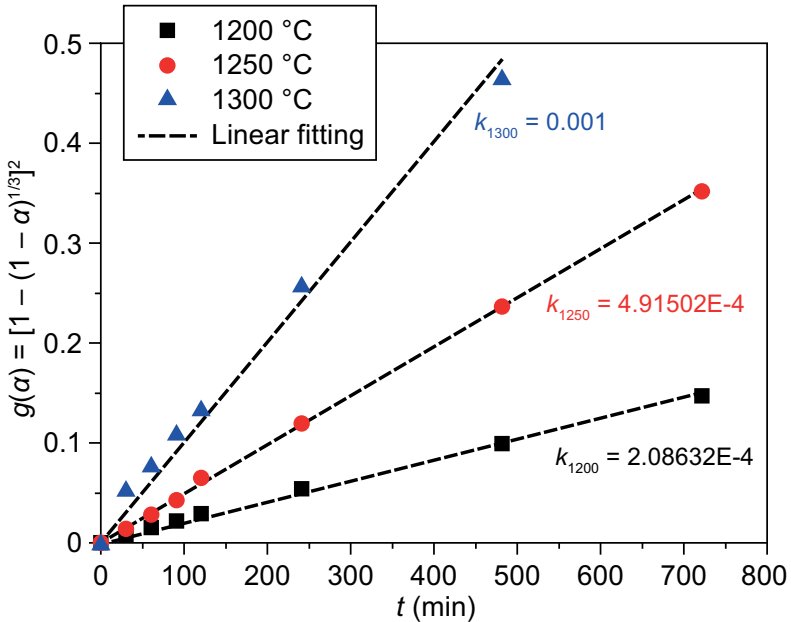

a) $\mathrm{C}_{4} \mathrm{~A}_{3} \$$

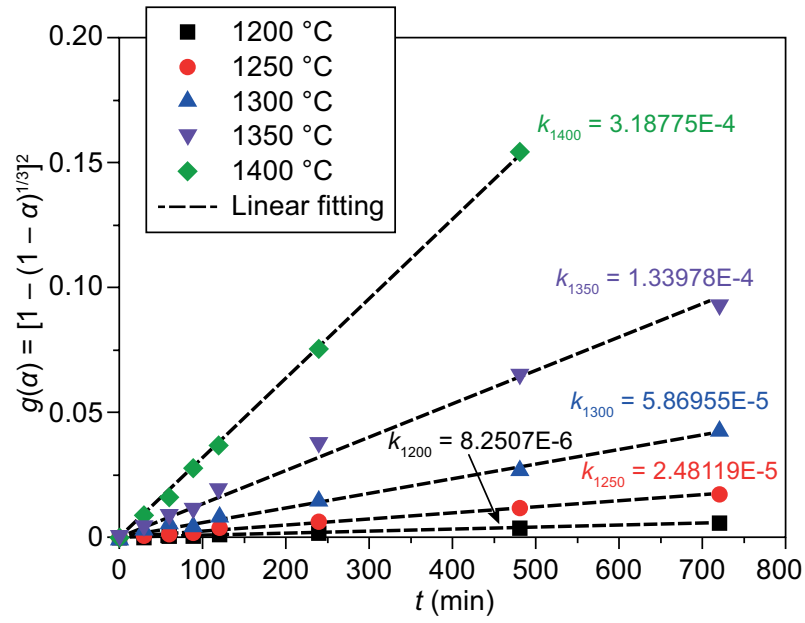

c) $\mathrm{C}_{3} \mathrm{BA}_{3} \$$

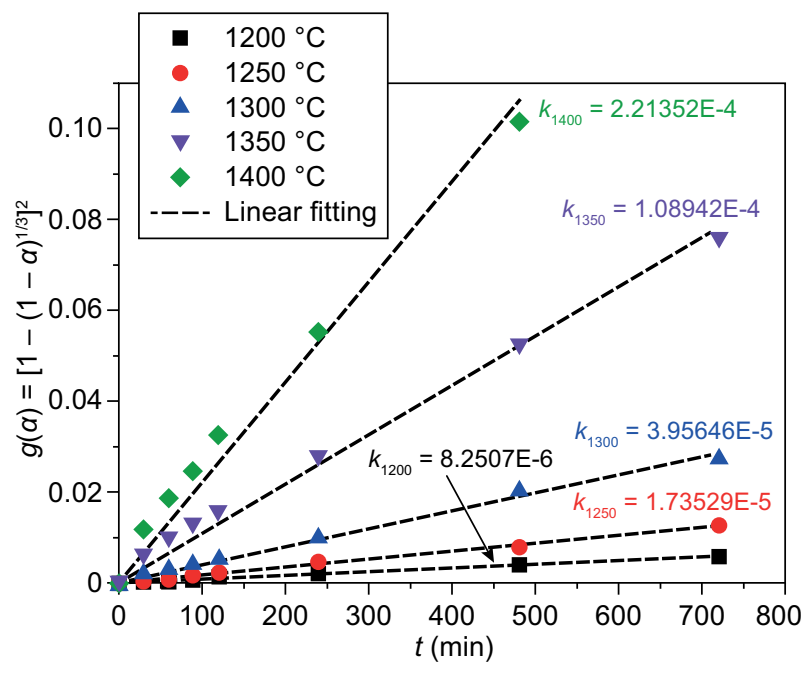

b) $\mathrm{C}_{3.5} \mathrm{~B}_{0.5} \mathrm{~A}_{3} \$$

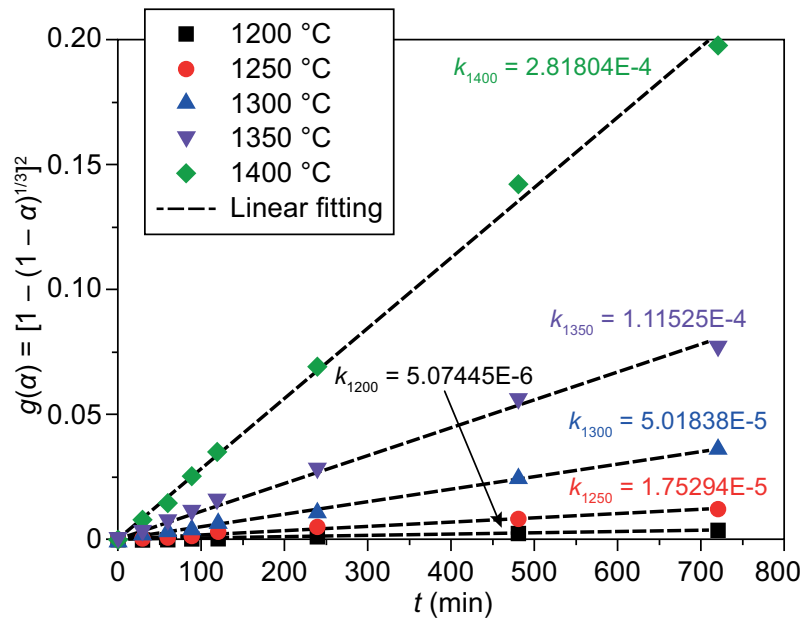

d) $\mathrm{C}_{2.5} \mathrm{~B}_{1.5} \mathrm{~A}_{3} \$$

Figure 4. The relationship curves of ' $f(\alpha)-\mathrm{K}_{\text {(TC) }} t$ ' of the $\mathrm{C}_{4-\mathrm{x}} \mathrm{B}_{x} \mathrm{~A}_{3} \$$ minerals (Figs. 4a-e represent the linear regression results of $\mathrm{C}_{4} \mathrm{~A}_{3} \$, \mathrm{C}_{3.5} \mathrm{~B}_{0.5} \mathrm{~A}_{3} \$, \mathrm{C}_{3} \mathrm{BA}_{3} \$, \mathrm{C}_{2.5} \mathrm{~B}_{1.5} \mathrm{~A}_{3} \$, \mathrm{C}_{2} \mathrm{~B}_{2} \mathrm{~A}_{3} \$$, respectively). (Continue on next page) 


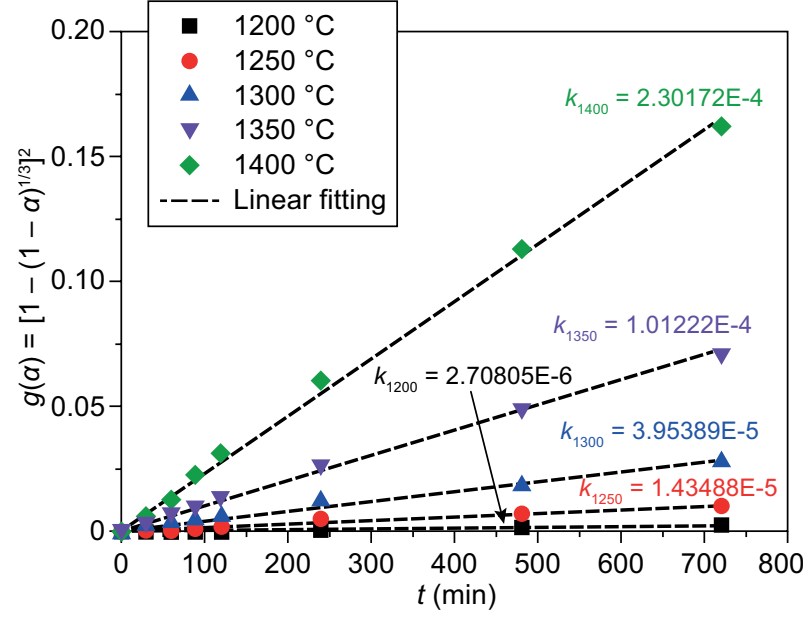

e) $\mathrm{C}_{2} \mathrm{~B}_{2} \mathrm{~A}_{3} \$$

Figure 4. The relationship curves of ' $f(\alpha)-\mathrm{K}_{(\mathrm{T} . \mathrm{C})} t$ ' of the $\mathrm{C}_{4-x} \mathrm{~B}_{x} \mathrm{~A}_{3} \$$ minerals.

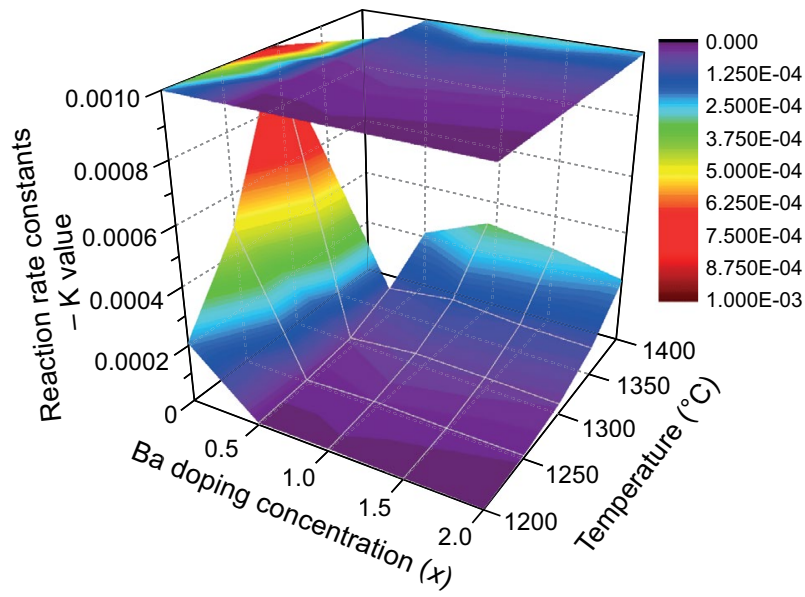

Figure 5. The reaction rate constants with the different Ba-doping concentrations and sintering duration.

a lower ' $k$ ' value than expected. This phenomenon is more obvious under the conditions of a higher temperature. As discussed above, it is probably caused by the sulfur volatilised from the $\mathrm{CaSO}_{4}$ decomposition, restricting the formation of ye' elimite. When the Ba-doping concentration is larger than $1.0\left(\mathrm{C}_{4-x} \mathrm{~B}_{x} \mathrm{~A}_{3} \$, x>1\right)$, the $\mathrm{BaSO}_{4}$ produced as the main sulfate-containing mesophase with a higher decomposition temperature will play an important role in the sulfur solidification.

The apparent activation energy

The apparent activation energy $\left(E_{a}\right)$ which could reflect the difficulty of the solid-state reaction, is the minimum energy required for the molecules to be converted to the active chemical component from the normal reactive states $[20,24,31,38,39,44] . E_{a}$ can be calculated from the Arrhenius equation (Equations 11-12) as follows,

$$
k=A \mathrm{e}^{-(E a / \mathrm{RT})}
$$

$$
\ln k=\ln A-\left(E_{a} / R T\right)
$$

where $A$ is the pre-exponential factor, $R$ represents the ideal gas constant $\left(8.314 \times 10^{-3} \mathrm{~kJ} \cdot \mathrm{mol}^{-1} \cdot \mathrm{K}^{-1}\right)$, ' $T$ ' indicates the reaction temperature $(k)$, respectively.

The linear fitting relation between $\ln k$ and $-1 / R T$ is shown in Figure 6 and the corresponding $E_{a}$ values are reported in Table 6. Obviously, it gradually increases with an increase in the Ba-doping concentration. A fitting analysis, seen in Figure 7 , depicts that the $E_{a}(y)$

Table 6. The apparent activation energy of the $\mathrm{C}_{4-\mathrm{x}} \mathrm{B}_{x} \mathrm{~A}_{3} \$$ minerals.

\begin{tabular}{cccccc}
\hline $\begin{array}{c}\text { Ba-doping } \\
\text { concentration }\end{array}$ & $x=0$ & $x=0.5$ & $x=1$ & $x=1.5$ & $x=2$ \\
\hline$E_{a}\left(\mathrm{~kJ} \cdot \mathrm{mol}^{-1}\right)$ & 302.158 & 344.472 & 370.451 & 405.939 & 446.194
\end{tabular}

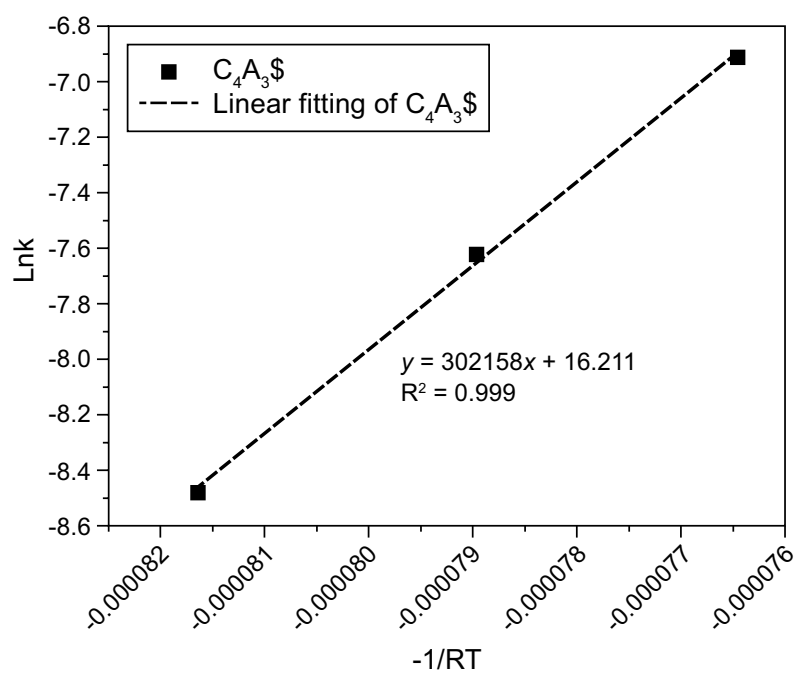

a) $\mathrm{C}_{4} \mathrm{~A}_{3} \$$

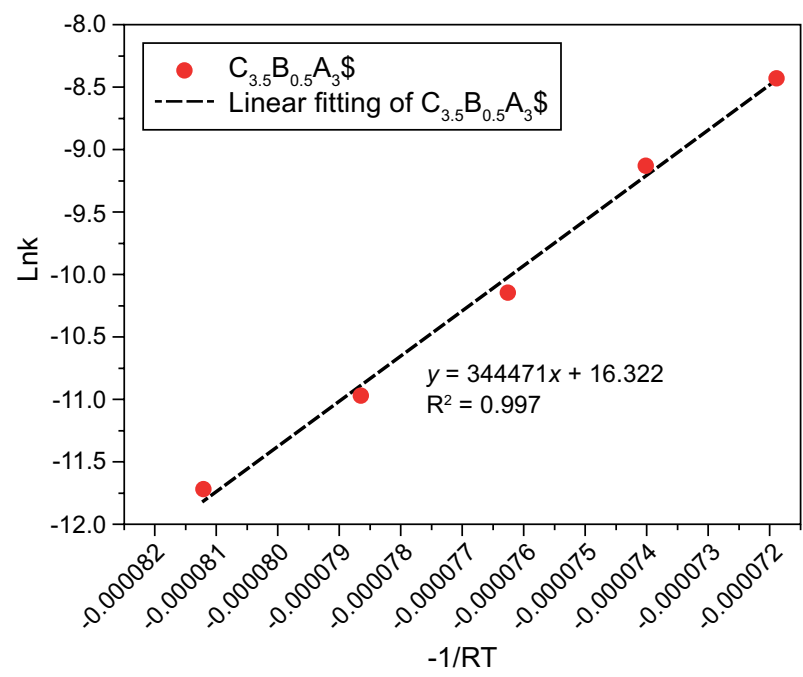

b) $\mathrm{C}_{3.5} \mathrm{~B}_{0.5} \mathrm{~A}_{3} \$$

Figure 6. The Arrhenius equation fitting the results of the $\mathrm{C}_{4-x} \mathrm{~B}_{x} \mathrm{~A}_{3} \$$ minerals. (Continue on next page) 


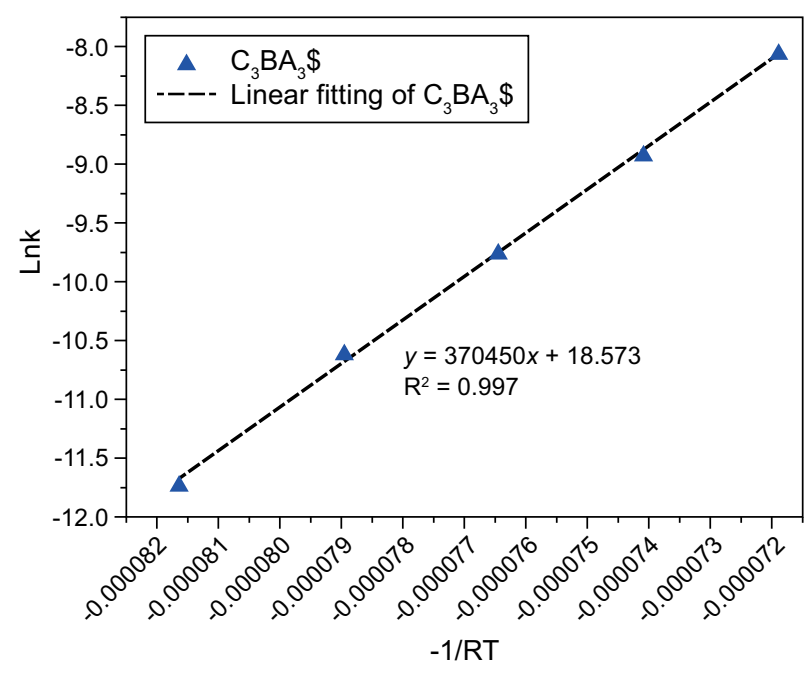

c) $\mathrm{C}_{3} \mathrm{BA}_{3} \$$

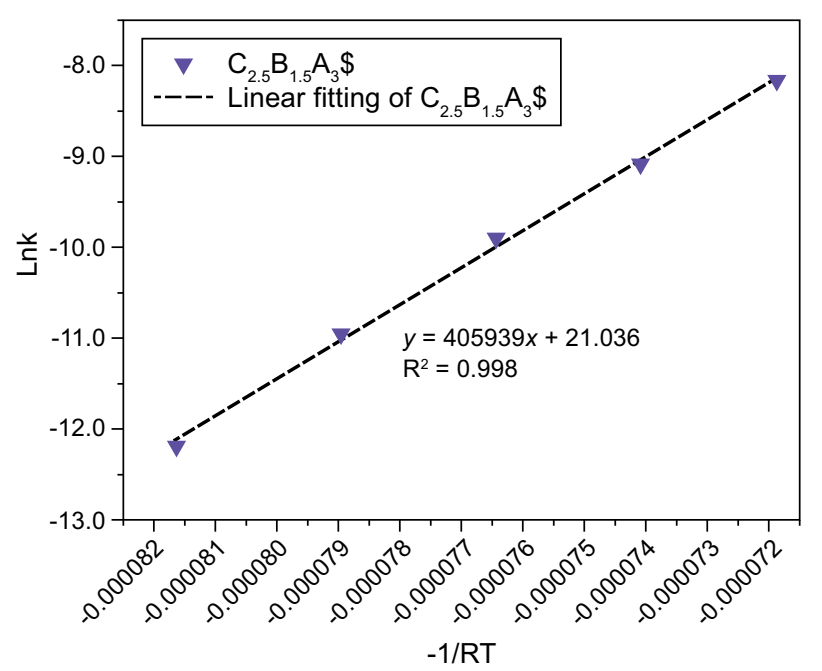

d) $\mathrm{C}_{2.5} \mathrm{~B}_{1.5} \mathrm{~A}_{3} \$$

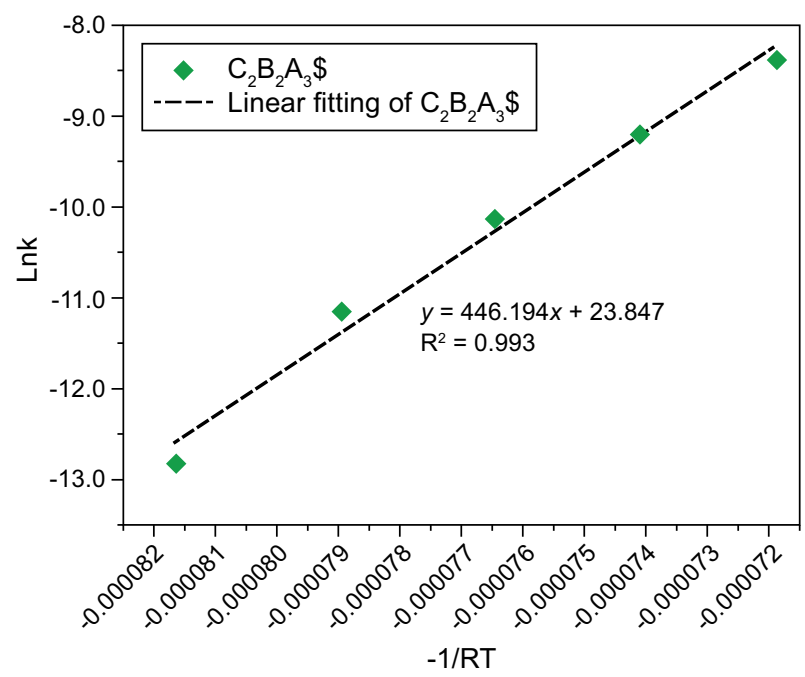

e) $\mathrm{C}_{2} \mathrm{~B}_{2} \mathrm{~A}_{3} \$$

Figure 6. The Arrhenius equation fitting the results of the $\mathrm{C}_{4-\mathrm{x}} \mathrm{B}_{x} \mathrm{~A}_{3} \$$ minerals. and the Ba-doping concentration $(x)$ can be well imitated with ' $y=71.9 x+304$ '. The goodness of the fit is as high as 0.992 . A previous study has reported that the activation energy of the Ba-doped ye'elimite formation is larger than the stoichiometric one [20]. Here, we demonstrate that ' $E_{a}$ ' has approximately linear growth with the amount of barium incorporation content. Li [29] proposed that $\mathrm{C}_{4} \mathrm{~A}_{3} \$$ formed originally from the basic ' $\mathrm{Al}-\mathrm{O}$ ' skeleton structure and then the ions of $\mathrm{Ca}^{2+}$ and $\mathrm{SO}_{4}{ }^{2-}$ diffused into the crystal structure. Compared with $\mathrm{Ca}^{2+}$, it is more difficult for $\mathrm{Ba}^{2+}$ to enter into the above skeleton structure, due to its larger ionic radius, to form the Ba-doped ye'elimite. So, it is easy to understand that the more barium that is doped, the higher energy barrier needs to be overcome. Therefore, it makes a higher impurity phase formed at the low sintering temperature, which is consistent with the Rietveld results above (Table 3 ).

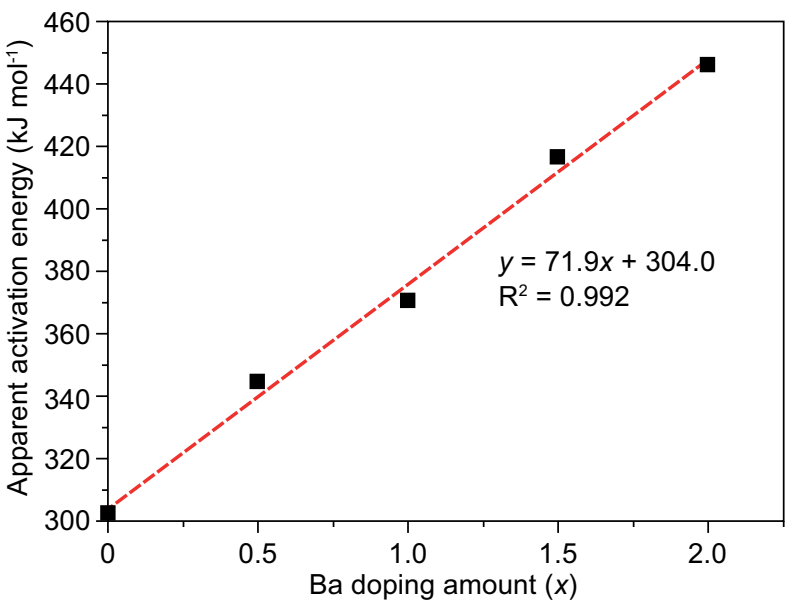

Figure 7. The relationship curves between the apparent activation energy and the Ba-doping concentration.

\section{CONCLUSIONS}

In this work, the solid-state reaction process of $\mathrm{C}_{4-x} \mathrm{~B}_{x} \mathrm{~A}_{3} \$$ minerals with different Ba-doping concentrations $(x=0,0.5,1,1.5$ and 2$)$ have been studied. The effect of the Ba-doping concentration on the formation kinetics is systematically discussed. The results above lead us to draw the following conclusions:

- $\mathrm{BaSO}_{4}$ is the essential intermediate phase for the formation of Ba-doped ye'elimite. The solid-state reaction processes of $\mathrm{C}_{4-x} \mathrm{~B}_{x} \mathrm{~A}_{3} \$$ are proposed as two main forms, corresponding to the cases in which the Ba-doping concentration $(x)$ is larger than and less than " 1 ", respectively. The same point is that the $\mathrm{BaSO}_{4}$ is the basis of the formation of the Ba-doped ye'elimite. When $x>1$, the different point is that the excess $\mathrm{BaO}$ continues to form the $\mathrm{BaAl}_{2} \mathrm{O}_{4}$ mineral with $\mathrm{Al}_{2} \mathrm{O}_{3}$.

- The Jander diffusion model shows the optimal fitting 
for a series of $\mathrm{C}_{4-x} \mathrm{~B}_{x} \mathrm{~A}_{3} \$$ minerals. An obvious linearity rising relationship exists between the apparent activation energy $\left(E_{a}\right)$ and the Ba-doping concentration $(x)$. A linear equation was obtained with a fitting goodness of 0.992 .

\section{Acknowledgments}

This research is supported by the National Key Research and Development Plan of China (No. 2016YFB0303505 and 2018YFD1101003), National Natural Science Foundation of China (No.U1806222, 51602126, and 51761145023), Key Laboratory of Advanced Civil Engineering Materials (Tongji University), Ministry of Education (202001), the Taishan Scholars Program, Case-by-Case Project for Top Outstanding Talents of Jinan, Youth Innovation Support Program of Shandong Colleges and Universities (2019KJA017), State Key Laboratory of Silicate Materials for Architectures (Wuhan University of Technology) (No.SYSJJ2018-12).

\section{REFERENCES}

1. Page C. L., (1975): Mechanism of corrosion protection in reinforced concrete marine structures. Nature, 258, 514-515. doi: $10.1038 / 258514 \mathrm{a} 0$

2. Lan W., Glasser F. P. (1996): Hydration of calcium sulphoaluminate cements. Advances in Cement Research, 8(31): 127-134. doi: 10.1680/adcr.1996.8.31.127

3. Péra J., Ambroise J. (2004): New applications of calcium sulfoaluminate cement. Cement and Concrete Research, 34(4): 671-676. doi: 10.1016/j.cemconres.2003.10.019

4. Fu X., Yang C., Liu Z., et al. (2003): Studies on effects of activators on properties and mechanism of hydration of sulphoaluminate cement. Cement and Concrete Research, 33(3): 317-324. doi: 10.1016/s0008-8846(02)00954-7

5. Hargis C. W., Kirchheim A P., Monteiro P J M., et al. (2013): Early age hydration of calcium sulfoaluminate (synthetic ye'elimite, C4A3S) in the presence of gypsum and varying amounts of calcium hydroxide. Cement and Concrete Research, 48, 105-115. doi: 10.1016/j.cemconres. 2013.03.001

6. Cuesta A., Álvarez-Pinazo G., Sanfélix S.G., Peral I., Aranda M.A.G., De la Torre A.G., (2014): Hydration mechanisms of two polymorphs of synthetic ye'elimite. Cement and Concrete Research, 63, 27-36. doi: 10.1016/j. cemconres.2014.05.010

7. Cuesta A., De la Torre A.G., Losilla E.R., Peterson V.K., Rejmak P., Ayuela A., et al. (2013): Structure, Atomistic Simulations, and Phase Transition of Stoichiometric Yeelimite. Chemistry of Materials, 25(9), 1680-1687. doi: $10.1021 / \mathrm{cm} 400129 \mathrm{z}$

8. Seryotkin Y. V., Sokol E. V., Kokh S. N., et al. (2019): Natural bentorite $-\mathrm{Cr}^{3+}$ derivate of ettringite: determination of crystal structure. Physics and Chemistry of Minerals, 46(6), 553-570. doi: 10.1007/s00269-019-01022-4

9. Sánchez-Herrero M. J., Fernández-Jiménez A., Palomo A., (2013): $\mathrm{C}_{4} \mathrm{~A}_{3} \$$ hydration in different alkaline media.
Cement and Concrete Research. 46, 41-49. doi: 10.1016/j. cemconres.2013.01.008

10. Liu X., Li Y., Zhang N., (2002): Influence of $\mathrm{MgO}$ on the formation of $\mathrm{Ca}_{3} \mathrm{SiO}_{5}$ and $3 \mathrm{CaO} \cdot 3 \mathrm{Al}_{2} \mathrm{O}_{3} \cdot \mathrm{CaSO}_{4}$ minerals in alite-sulphoaluminate cement. Cement and Concrete Research, 32(7), 1125-1129. doi: 10.1016/s0008-8846(02) 00751-2

11. Xin C., (2015): Development and Application of Barium (Strontium) Calcium Sulphoaluminate Cement. Journal of the Chinese Ceramic Society. 43(10), 1458-1466. doi: 10.14062/j.issn.0454-5648.2015.10.16

12. Xin C., Jun C., Lingchao L., et al. (2000): Study of Babearing calcium sulphoaluminate minerals and cement. Cement and Concrete Research, 30(1), 77-81. doi: 10.1016/ s0008-8846(99)00204-5

13. Valenti G., Santoro L., Garofano R., (1987): High-temperature synthesis of calcium sulphoaluminate from phosphogypsum. Thermochimica Acta, 113, 269-275. doi: 10.1016/0040-6031(87)88330-2

14. Ma S., Shen X., Huang Y., Zhong B., (2008): Effect of CuO on the formation mechanism of calcium sulphoaluminate. Journal of Wuhan University of Technology-Mater. 23(4), 518-21. doi: 10.1007/s11595-006-4518-8

15. Majling J, Sahu S, Vlna M, et al. (1993): Relationship between raw mixture and mineralogical composition of sulphoaluminate belite clinkers in the system $\mathrm{CaO} \mathrm{SiO}_{2}$ $\mathrm{Al}_{2} \mathrm{O}_{3} \mathrm{Fe}_{2} \mathrm{O}_{3} \mathrm{SO}_{3}$. Cement and Concrete Research, 23(6), 1351-1356. doi: 10.1016/0008-8846(93)90072-h

16. P. Arjunan M.R.S., Della M. Roy., (1999): Sulfoaluminatebelite cement from low-calcium fly ash and sulfur-rich. Cement and Concrete Research, 29, 1305-1356. doi: 10.1016/s0008-8846(99)00072-1

17. Sahu S., Majling J., (1993): Phase compatibility in the system $\mathrm{CaO}-\mathrm{SiO}_{2}-\mathrm{Al}_{2} \mathrm{O}_{3}-\mathrm{Fe}_{2} \mathrm{O}_{3}-\mathrm{SO}_{3}$ referred to sulphoaluminate belite cement clinker. Cement and Concrete Research, 23(6), 1331-1339. doi: 10.1016/0008-8846(93)90070-p

18. Ma B., Li X., Mao Y., et al., (2013): Synthesis and characterization of high belite sulfoaluminate cement through rich alumina fly ash and desulfurization gypsum. Ceramics Silikáty, 57(1), 7-13. doi: 10.1016/s0008-8846(99)00072-1

19. Chang J., Cheng X., Liu F., et al. (2001): Influence of fluorite on the Ba-bearing sulphoaluminate cement. Cement and Concrete Research, 31(2), 213-216. doi: 10.1016/ s0008-8846(00)00450-6

20. Huang Y., Wang S., Gong C., Zhao Y., Lu L., (2013): Study on Isothermal Formation Dynamics of Calcium Barium Sulphoaluminate Mineral. Journal of Inorganic and Organometallic Polymers and Materials. 23(5), 1172-1176. doi: 10.1007/s10904-013-9883-0

21. Zhang J., Gong C., Wang S., Lu L., Cheng X., (2015;): Effect of strontium oxide on the formation mechanism of dicalcium silicate with barium oxide and sulfur trioxide. Advances in Cement Research, 27(7),381-387. doi: 10.1680/ adcr.14.00021

22. Lingchao L., Jun C., Xin C., et al. (2005): Study on a cementing system taking alite-calcium barium sulphoaluminate as main minerals. Journal of Materials Science, 40(15), 4035-4038. doi: 10.1007/s10853-005-2005-9

23. Lu L., Lu Z., Liu S., Wang S., Cheng X., (2009): Durability of alite-calcium barium sulphoaluminate cement. Journal of Wuhan University of Technology-Mater, 24(6), 982-983. doi: 10.1007/s11595-009-6982-4

24. Wang S., Huang Y., Gong C., Lu L., Cheng X. (2014): 
Formation mechanism of barium calcium sulfoaluminate mineral. Advances in Cement Research. 26(3), 169-76. doi: 10.1680/adcr.13.00016

25. Zhao P., Liu X., Wu J., et al. (2013): Rietveld quantification of $\gamma-\mathrm{C}_{2} \mathrm{~S}$ conversion rate supported by synchrotron $\mathrm{X}$-ray diffraction images. Journal of Zhejiang University SCIENCE A, 14(11), 815-821. doi: 10.1631/jzus.a1300215

26. Aranda M.A.G., De la Torre A.G., Leon-Reina L., (2012): Rietveld Quantitative Phase Analysis of OPC Clinkers, Cements and Hydration Products. Reviews in Mineralogy and Geochemistry. 74(1),169-209. doi: 10.2138/rmg.2012.74.5

27. Álvarez-Pinazo G., Cuesta A., García-Maté M., Santacruz I., Losilla E.R., la Torre A.G.D., et al. (2012): Rietveld quantitative phase analysis of Yeelimite-containing cements. Cement and Concrete Research. 42(7), 960-71. doi: 10.1016/j.cemconres.2012.03.018

28. El Khessaimi Y., El Hafiane Y., Smith A., Trauchessec R., Diliberto C., Lecomte A. (2018): Solid-state synthesis of pure ye'elimite. Journal of the European Ceramic Society. 38(9), 3401-11. doi: 10.1016/j.jeurceramsoc.2018.03.018

29. Li X., Zhang Y., Shen X., Wang Q., Pan Z., (2014): Kinetics of calcium sulfoaluminate formation from tricalcium aluminate, calcium sulfate and calcium oxide. Cement and Concrete Research. 55, 79-87. doi: 10.1016/j.cemconres. 2013.10.006

30. Li H., Zhang H., Li L., Ren Q., Yang X., Jiang Z., et al. (2019): Utilization of low-quality desulfurized ash from semi-dry flue gas desulfurization by mixing with hemihydrate gypsum. Fuel. 255:115783. doi: 10.1016/j.fuel. 2019.115783

31. Zhao J., Chang J., (2017): Kinetic Analysis for Formation Process of Sr-Bearing Ye'elimite. Journal of Inorganic and Organometallic Polymers and Materials. 27(6), 1861-1869. doi: 10.1007/s10904-017-0653-2

32. Xin C., Chang J., Lingchao L., Liu F., Bing T., (2000): Study of Ba-bearing calcium sulphoaluminate minerals and cement. Cement and Concrete Research. 30(1), 77-81. doi: 10.1016/s0008-8846(99)00204-5

33. Ali M. M., Gopal S., Handoo S. K., (1994): Studies on the formation kinetics of calcium sulphoaluminate. Cement and Concrete Research, 24(4): 715-720. doi: 10.1016/00088846(94)90196-1

34. El Khessaimi Y., El Hafiane Y., Smith A., (2019): Ye'elimite synthesis by chemical routes. Journal of the European Ceramic Society, 39(4): 1683-1695. doi: 10.1016/j.jeurceramsoc.2018.10.025

35. Li J., Ma B., Zhou C., et al. (2014): Study on mechanism of chemical activation for minerals of high belite-calcium sulfoaluminate clinker. Journal of Sustainable CementBased Materials, 3(1): 13-23. doi: 10.1080/21650373.2013. 843476

36. Huang Y., Xu C., Li H., et al. (2019): Utilization of the black tea powder as multifunctional admixture for the hemihydrate gypsum. Journal of Cleaner Production, 210, 231-237. doi: 10.1016/j.jclepro.2018.10.304

37. Yang X., Liu J., Li H., et al. (2019): Effect of triethanolamine hydrochloride on the performance of cement paste. Construction and Building Materials, 200, 218-225. doi: 10.1016/j.conbuildmat.2018.12.124

38. Guo H., Xie J., (2011): Thermodynamics and kinetics of calcium sulphoaluminate. Journal of Wuhan University of Technology-Mater. 26(4) 719-722. doi: 10.1007/s11595011-0300-7

39. Guo H., Xie J., (2010): Kinetics of Desulfuration Product Sulphoaluminate Calcium. Advanced Materials Research. 113-116:1814-1817. doi: 10.4028/www.scientific.net/amr. 113-116.1814

40. Ali M. M., Agarwal S. K., Agarwal S., et al. (1995): Kinetics and diffusion studies in $\mathrm{BaAl}_{2} \mathrm{O}_{4}$ formation. Cement and Concrete Research, 25(1), 86-90. doi: 10.1016/0008-8846 (94)00116-g

41. Luo Y. R., (2007) Comprehensive handbook of chemical bond energies. CRC press, doi: 10.1201/9781420007282

42. Khawam A., Flanagan D. R., (2006): Solid-state kinetic models: basics and mathematical fundamentals. The journal of Physical Chemistry B, 110(35), 17315-17328. doi: 10.1002/chin.200647223

43. Fătu D., (1988): Kinetic models for solid-solid reactions. Thermochimica Acta, 131, 65-71. doi: 10.1016/0040-6031 (88)80058-3

44. Puertas F., Varela M. T. B., Molina S. G., (1995): Kinetics of the thermal decomposition of C4A3S in air. Cement and Concrete Research, 25(3), 572-580. doi: 10.1016/00088846(95)00046-F 